\title{
Pharmaceutical patenting in the European Union: reform or riddance
}

\author{
Livio Garattini ${ }^{1} \cdot$ Marco Badinella Martini ${ }^{1} \cdot$ Pier Mannuccio Mannucci ${ }^{2}$
}

Received: 1 November 2021 / Accepted: 2 November 2021 / Published online: 15 November 2021

(c) Società Italiana di Medicina Interna (SIMI) 2021

\section{Dear Editor,}

The COVID-19 pandemic has put again pharmaceutical patenting in the spotlight on account of vaccines. Here we discuss whether it is still possible to achieve a balance between commercial incentives guaranteed by patents to the industry and the regulatory framework meant to support public interests within the European Union (EU).

Intellectual property (IP) refers to creations of the intellect such as inventions. The law assigns the creators a monopoly through IP rights (e.g. copyrights, patents and trademarks), which guarantee them protection for a certain period during which they can benefit commercially from the invention. In pharmaceuticals the patent is by far the most exploited IP tool by industry to protect research and development $(R \& D)$ investments [1]. A pharmaceutical company can apply for different types of patents regarding a specific drug, a particular use of it, a manufacturing process or a newer formulation of an already known drug.

Differently from specific regulation on pharmaceuticals, general patent regulation is part of the commercial law and lies outside the public legislation. Patents are still national in the EU, thus valid only in the countries where the patentee has applied. Although the patent systems of the member states are substantially similar because key provisions have been adopted consistently with the European Patent Convention (EPC), the patent system is not yet entirely harmonized in the EU. Patent claims can be filed through the single national patent offices or the European Patent Office (EPO), the executive body created in 1977 to grant patents in different European countries under the EPC. EPO is not legally bound to the EU, has a staff of around 7,000 (more than half

Livio Garattini

livio.garattini@marionegri.it

1 Institute for Pharmacological Research Mario Negri IRCCS, Ranica, BG, Italy

2 IRCCS “Ca' Granda Maggiore Policlinico” Hospital Foundation, Milan, Italy in the Munich branch specialized in pharmaceuticals) and is self-financing, covering all its expenditure from patent fees.

As in most developed countries, patent protection in the EU formally lasts 20 years. Nevertheless, in response to the perceived inadequacy of the current market protection length generated by pharmaceutical patents compared to other goods, mainly due to the long registration process of drugs before market approval, it is possible to extend the original patent on drugs for up to 5 years through (only) one supplementary protection certificate (SPC). Moreover, because no common European patent law yet exists, each nation still keeps its own rules for patent infringement. In most states, the national patent laws include regulations that allow actions for a limited term before the patent expires, which could be otherwise considered infringements. For instance, the 'Bolar' exemption allows clinical trials for the development and approval of generics and biosimilars before the originator patent expires. However, since these exemptions were harmonized in the EU through directives, which are legal provisions that allow member states some freedom and discretion in domestic applications, there are still some differences at national level and this raises legal uncertainty throughout Europe. Last but not least, it is worth mentioning the extreme option of a compulsory license-often cited for anti-COVID-19 vaccines in this period-that, due to a compelling public interest, is allowed in the EU, although hardly ever applied in practice. Further opportunities for longer market exclusivity for the pharmaceutical industry have been introduced more recently in the EU. For instance, a 10-year market exclusivity is granted to encourage $R \& D$ in the field of orphan drugs, during which no similar orphan medicinal product can be approved even if based on a full documentation. Accordingly, the present situation of IP for pharmaceuticals in the EU is quite confusing and of very hard understanding for non-experts in legal issues [2].

In general, pharmaceutical patents result from close collaboration between scientists and attorneys, two very different types of professionals [3]. The first crucial decision of attorneys concerns the timing of patent application, which can be filed either as soon as the drug is synthesized 
to prevent others from copying or postponed until the very first trial to lengthen the protection [4]. Later, another main result expected from attorneys is to extend patent protection of successful drugs by generating an invention cascade of secondary patents based on modifications to the first invention. Typical examples of secondary patenting have been new indications, formulations and/or dosages, 'me-too' drugs and fixed-dose drug associations. These ever greening strategies are often followed by originator companies in order to slow down the launch of cheaper off-patent medicines. This generates many costly litigations, which can be ultimately considered a waste of public money in a societal perspective, because they would not be supported without third payers' funding in health care [2]. Yet data and marketing exclusivity provisions can be also manipulated, e.g. the regulation on orphan drugs opened the way to many new indications for old anticancer drugs on rare tumors. Not surprisingly, the present regulatory framework on pharmaceutical IP exclusivity has been criticized by many experts [1,5], and radical proposals of de-linking R\&D investments from financial returns have been raised to make regulations more responsive to the health needs of patients and society.

In light of the harsh debate on pharmaceutical IP exclusivity, we figure out an alternative European scenario based on three key points to (re)establish a more acceptable tradeoff between public and private interests in pharmaceuticals without necessarily cancelling patents.

- First, the main radical change should concern the current management of pharmaceutical patents by EPO and the parallel network of national offices. EPO is a huge organization totally out of control from the public health viewpoint and entirely funded by patent fees, thus fully prone to financial conflicts of interest. On the other hand, the domestic offices are inadequate for managing difficult patents like pharmaceuticals, in which they can just play a merely administrative role. We feel it is time to make the EU partly responsible (and financially accountable) for pharmaceutical patents by introducing a specific agency dedicated to them (potentially extendable to medical devices).

- The second main issue to be faced is the excess of discretion by pharmaceutical companies in filing patents. Primary patents could be limited to drugs with one declared indication, then secondary patents should be granted only to new and different therapeutic indications (i.e. for disease groups substantially different from the first one), ruling out all types of patents on manufacturing processes and formulations. This should help reduce the court litigations, as well as the claims for compulsory licenses, which could be constrained to extreme circumstances requiring huge production volumes (like the current pandemic) when the patentee refuses voluntary licensing.
- The third important issue to cope with is the present length of market exclusivity on drugs, much shorter compared to that of the other goods. A sound move to re-align such duration could be to warrant a market exclusivity of 15 years only for compounds that start a first clinical trial within 5 years from the granting date, thus daunting opportunistic early filing of drugs with still uncertain therapeutic indications. Afterwards, the duration could be progressively reduced, reflecting the delay in trialing, i.e. 14 years of exclusivity for drugs starting the first trial during the sixth year after the granting date and so on. At the same time, the SPC tool and all the additional regulations on data and market exclusivity could be ruled out. Although inspired by positive principles, also these specific provisions are inevitably open to manipulation by industry.

To conclude, the current regulation of pharmaceutical patents somehow conflicts with the general patent concept, which results from a bargain of IP rights in exchange for inventions disclosure. Since secrecy is the only plausible alternative to patenting, any patented good should be reproducible by definition. Moreover, it is worth noting that discoveries in pharmaceuticals can flow into and depend on each other, with downstream marketed products often generated by upstream discoveries from publicly funded basic research. Indeed this seems to be the right period for reforming the EU regulation on pharmaceutical patenting in the wake of continental welfare tradition.

Funding No sources of funding were used to conduct this study or prepare this manuscript.

\section{Declarations}

Conflict of interest Livio Garattini, Marco Badinella Martini and Pier Mannuccio Mannucci have no conflicts of interest directly relevant to this article.

\section{References}

1. Cockburn I, Long G (2015) The importance of patents to innovation: updated cross-industry comparisons with biopharmaceuticals. Expert Opin Ther Pat 25(7):739-742

2. Garattini L, Padula A (2017) Between pharmaceutical patents and European patients: is a compromise still possible? Expert Opin Ther Pat 27(10):1073-1076

3. Gupta H, Kumar S, Roy S, Gaud R (2010) Patent protection strategies. J Pharm Bioallied Sci 2(1):2-7

4. Raj GM, Priyadarshini R, Mathaiyan J (2015) Drug patents and intellectual property rights. Eur J Clin Pharmacol 71(4):403-409 
5. Dutfield G (2017) Healthcare innovation and patent law's "pharmaceutical privilege": is there a pharmaceutical privilege? And if so, should we remove it? Health Econ Policy Law 12(4):453-470
Publisher's Note Springer Nature remains neutral with regard to jurisdictional claims in published maps and institutional affiliations. 